\title{
Longview District Operations and Maintenance Headquarters
} Environmental Assessment DOE/EA--0523 DE93 002205 


\section{LONGVIEW DISTRICT OPERATIONS AND MAINTENANCE HEADQUARTERS ENVIRONMENTAL ASSESSMENT}

\subsection{NEED FOR ACTION}

Bonneville Power Administration (BPA) operations and maintenance staff are presently based at a headquarters next to the Longview Substation (Figure 1). These headquarters buildings, however, were built in 1941 and have deteriorated to the point of needing ixtensive repair. They also lack sufficient inside storage space. New buildings cannot be constructed on the site because of surrounding development. In addition, the site is within an area exposed to industrial fallout (coal tar pitch and metallic particles) that may be damaging buildings, equipment, and vehicles. BPA is concerned about the potential health risk to headquarters staff from the fallout.

In light of these problems, BPA proposes to construct a new operations and maintenance headquarters at a different location, and to demolish the existing headquarters.

\subsection{ALTERNATIVES}

\subsection{NO ACTION}

The existing headquarters would be used to maintain the Longview Substation and other BPA substations in the area.

\subsection{THE PROPOSED ACTION: CONSTRUCT A NEW OPERATIONS AND MAINTENANCE HEADQUARTERS AT THE SOLO MOUNTAIN SITE}

BPA proposes to build a new maintenance headquarters on a site of about 6 acres near the intersection of Memorial Park Drive and 38 th Avenue (Figure 1). This site, known as Solo Mountain, offers quick access (about a 5-minute drive) to the Longview Substation. It is not exposed to the industrial fallout found at the existing headquarters. The new headquarters would consist of one ta four buildings totalling about 0.5 acre $(24,000$ square feet). The single-story building(s) would contain of $f$ ices, storage areas, workshops, and garages. The garages would hare lofts to accommodate cranes on maintenance vehicles. Paved parking spaces for 23 employee and 6 visitor vehicles would be located near the buildings. About 5 or 6 times pur year, BPA helicopters may use an adjacent paved area. Fuels for BPA vehicles would be supplied from a 1,000-gallon gasoline tank and a 550-gallon diesel tank. Both above-ground tanks would be double-walled and would have leak detection systems. A 20 to 50-foot tower would support a microwave communications dish. Since most of Longview is exposed to potential chemical leaks and spills from local industries, a chemical hazard detection system would be used to warn BPA employees of chlorine or other hazards. Paved storage areas and gravelled or landscaped areas would be incorporated into the site, and most of the site would be fenced for security. 


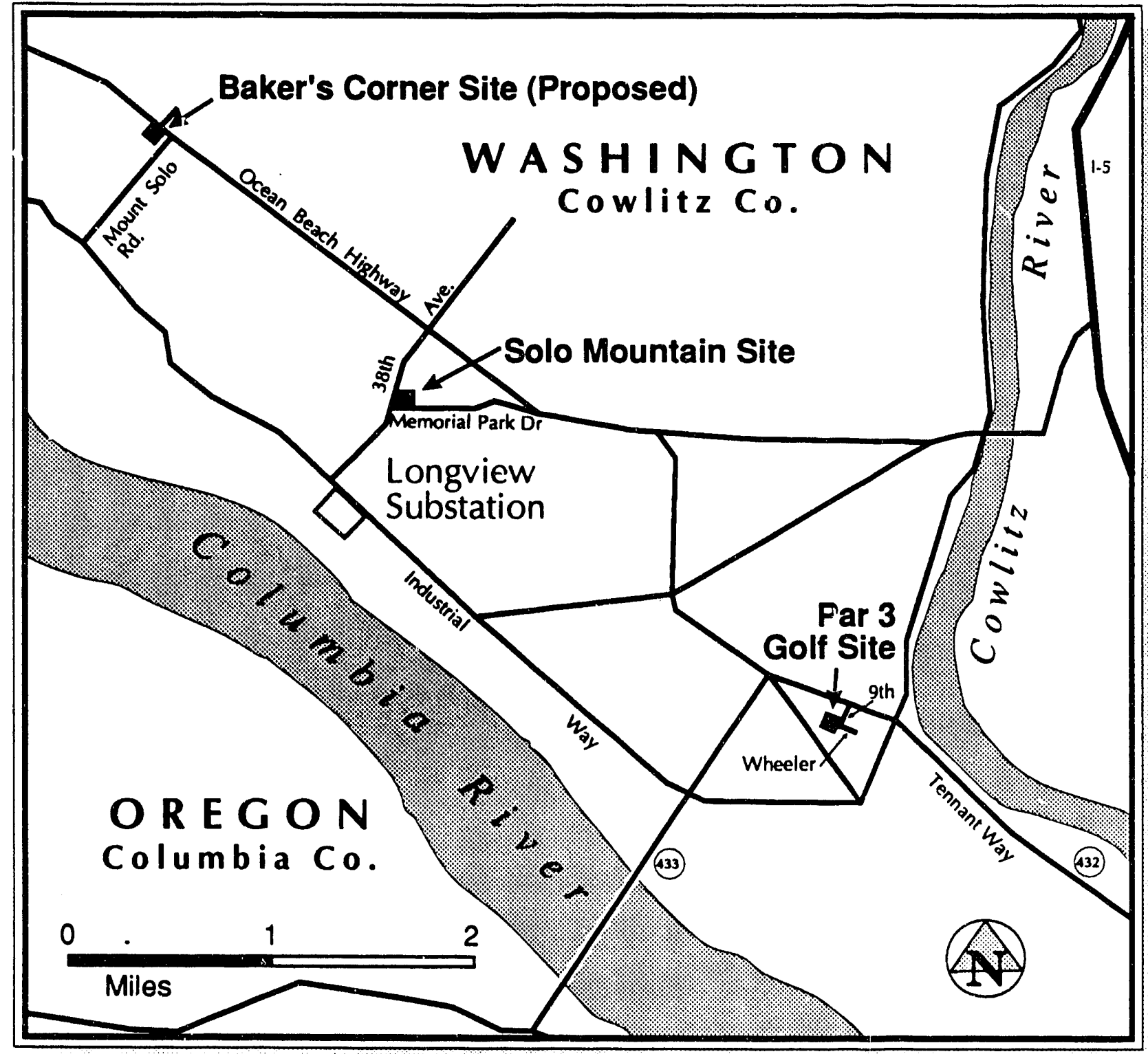

Proposed and Alternative Sites for the Longview District Operations and Maintenance Headquarters in Longview, Washington.

Figure 1 


\subsection{ALTERNATIVE SITE FOR THE MAINTENANCE HEADQUARTERS}

The Par 3 Golf alternative site is located at the intersection of 9 th Avenue and Wheeler Street (Figure 1). Driving time from this 15-acre site to the Longriew Substation is about 15 minutes. Like the proposed site, it is not exposed to the industrial fallout found at the existing headquarters. The facilities would be the same as those described for the proposed site at Solo Mountain.

\subsection{ALTERNATIVE SITE ELIMINATED FROM CONSIDERATION}

A site known as Baker's Corner was located near the intersection of Ocean Beach Highway and Mount Solo Road. Since the "Federal Manual for Identifying and Determining Jurisdictional Wetlands" defines this site as a jurisdictional wetland, it has been eliminated from further consideration.

\subsection{ENVIRONMENTAL IMPACTS OF THE PROPOSED ACTION AND ALTERNATIVES}

Under the "No Action" alternative, BPA staff would continue using undersized, outdated, and deteriorating headquarters buildings. The quality and efficiency of operations and maintenance activities would decline. BPA would remain concerned about the potential health risk to headquarters staff from industrial fallout. The impacts of constructing a new headquarters are discussed below.

Both the proposed site and the alternative site are zoned as manufacturing districts and classified as light industrial in the City of Longview's Comprehensive Plan. They are within the City of Longview's Urban Growth Boundary. Constructing the headquarters at either site would, therefore, be consistent with City land use plans.

BPA's maintenance headquarters would add a small amount of traffic to nearby streets. Fifteen to 17 personal employee vehicles would enter and leave the headquarters at the beginning and end of each workday. About 10 government service vehicles would enter and leave the headquarters at various times during the day. Traffic increases would not be noticeable on major streets near either site.

A BPA Wildlife Biologist conferred with U.S. Fish and Wildlife Service regional staff and determined that the project, at either site, would not affect the bald eagle or the peregrine falcon (the only listed or proposed threatened or endangered species in the area). The habitats that would be modified by the project are not typically used by eagles or falcons.

The proposed site is covered by sand, cobble, and concrete on top of about 4 feet of fill material. The history of the site does not suggest the presence of hazardous materials. Furthermore, BPA sampled the site on April 23, 1991, and found only trace amounts of barium, chromium, and lead that were far below U.S. Environmental Protection Agency regulatory limits. The alternative site was not studied. As an operational golf course, the Par 3 Golf site is covered by turfgrass. Canada thistle, bull thistle, and tansy ragwort grow at the 
Solo Mountain site and along the edges of the Par 3 Golf site. At either site, BPA would follow its noxious weed policy to ensure that noxious weeds would not pose problems to surrounding lands.

Section 404 of the Clean Water Act, passed in 1975, addresses the placement of fill material in wetlands. Because the proposed Solo Mountain site has been covered by fill since 1970, the Federal government does not have jurisdiction here and would not protect the site as a wetland. A visual inspection of the Par 3 Golf site and soil samples taken next to this site did not indicate the presence of a wetland. The Cowlitz County Department of Community Development does not consider either of the sites to be within floodplains. Cowlitz County is not included in the list of counties covered by the Coastal Zone Management Act. The sites are not in designated shoreline areas. No discharges into waters of the United States are proposed.

No impacts on drinking water sources are expected from constructing the maintenance headquarters at either site. Surface and stormwater run-off would enter the City or County stormwater system and would meet all applicable Federal, State, and local standards. 0il and water separators, detention basins, and other pollution control devices would be used where required. Polychlorinated biphenyls ( $\mathrm{PCB}$ 's) would not be stored; however, trucks carrying PCB-containing equipment may occasionally visit the headquarters. Small amounts of PCB's may also be present for a short time while equipment parts such as bushings are serviced. Other toxic or hazardous materials (such as herbicides, engine oil, or solvents) would be stored and disposed of in accordance with applicable Federal, State, and local regulations including the Resource Conservation and Recovery Act, the Toxic Substance Control Act, the Comprehensive Environmental Response, Compensation, and Liability Act, and the Clean Water Act. BPA would develop a Spill Prevention Control and Countermeasure Plan for the headquarters to handle any potential hazardous material spills or leaks.

Negligible air quality impacts would result from construction and operation of the maintenance headquarters at either site. Minimal tree clearing and debris burning would be required. Dust and emissions caused by the construction would be of low quantity and short duration. The headquarters would not emit enough pollutants to change air quality. Therefore, air quality impacts would be minimal.

Consultation with the Washington State Office of Archaeology and Historic Preservation (SOAHP) found that no historic properties are known to exist at proposed or alternative maintenance headquarters sites, but it is possible that the sites contain undiscovered historic resources. A BPA field survey conducted by a professional archaeologist found no substantial evidence of unknown archeological materials in either of the sites. If historic resources were to be discovered during construction, BPA would consult with SOAHP officials and a professional archaeologist to develop methods for avoiding impacts on important resources. The project would therefore not affect historic resources. 
The presence of the maintenance headquarters would not have adverse visual impacts. Locating the headquarters at the Solo Mountain site would upgrade that disturbed site and the surrounding industrial area. Residents near the Par 3 Golf site would see the headquarters buildings only when using 9 th Avenue or Wheeler Street. Few travelers use 9 th Avenue or Wheeler Street.

Neither of the sites is within or adjacent to Wild and Scenic Rivers, National Trails, Wilderness Areas, or other recreation aress on public lands. Building the headquarters at the Par 3 Golf site would partially remove an existing golf course, thus decreasing golfing opportunities in the Longview area.

Energy conservation design features will be incorporated into the maintenance headquarters under BPA's Energy Smart Design Program. This program aims to improve the energy efficiency of BPA's commercial buildings in the region. The design would aim at a minimum 30 percent energy savings over the basic requirements of the Northwest Energy Conservation Code.

Demolishing the existing building would have no adverse effects on the environment. The building structure contains detectable amounts of asbestos and lead; therefore, qualified contractors would demolish the building according to State and Federal regulations and trarsport the debris to an EPA/State-approved landfill.

\subsection{CONCLUSIONS}

Building the Longview Operations and Maintenance Headquarters at the proposed site (Solo Mountain) or the alternative site (Par 3 Golf) would be consistent with the City of Longview's land use plans. The project would not affect wildlife, native vegetation, floodplains or wetlands, coastal zones, shoreline management areas, drinking water supplies, historic resources, or air quality. Traffic levels would be minimally affected. Compared to the alternative site, the proposed site would cost less and would provide better access to the Longview Substation. Demolishing the existing building would create no adverse environmental impacts.

Consultation with interested and affected agencies, organizations, and persons revealed little controversy and no unusual environmental concerns regarding headquarters construction. The health of BPA employees would be protected with a chemical hazard detection system.

\subsection{AGENCIES AND PERSONS CONSULTED}

City of Longview; Planning and Building Department and Engineering Department. Cowlitz County; Departments of Community Development, Public Works, and

Noxious Weed Control.

Hazcon, Inc.

U S. Soil Conservation Service.

U.S. Fish and Wildlife Service

Washington State Department of Transportation.

Washington State of $\mathrm{f}$ ice of Archeology and Historic Preservation. 


\section{DEPARTMENT OF ENERGY}

Bonneville Power Administration

Longview District Operations and Maintenance Headquarters

Finding of No Significant Impact

AGENCY: Bonneville Power Administration (BPA), DOE.

ACTION: Finding of No Significant Impact (FONSI).

SUMMARY: The existing Longview District Operations and Maintenance Headquarters is too small and outdated and is exposed to industrial fallout (coal, tar, pitch and metallic particles) that may be damaing equipment. BPA is also concerned about the potential health rigk to the headquarters staff from the fallout. BPA, therefore, proposes to build a new maintenance headquarters and demolish the existing headquarters.

The new headquarters would te located at a site known as Solo Mountain; an alternative site is called Par 3 Golf. The Solo Molntain site would cost less than the Par 3 Golf site and would provide better access to the Longview Substation. BPA could also choose a "No Action" alternative and continue to use the existing headquarters.

BPA has prepared an Environmental Assessment (DOE/EA-0523) evaluating the proposed project. Under the "No Action" alternative, BPA staff would continue using undersized, outdated, and deterfotating headquarters buildings. The quality and efficiency of operations and maintenance activities would decline, and BPA would remain concetned about the potential health risk to the staff. Constructing the maintenance headquarters at either the proposed or alternative $s^{\text {ite }}$ would not cause significant environmental impact on wildlife, native 
vegetation, floodplains or wetlancs, coastal zones, shoreline management areas, drinking water suppiies, air quality, historic resources, traffic levels, or local land use plans. The existing maintenance headquarters building contains asbestos and lead; therefore, qualified contractors would demolish the building according to State and Federal regulations and transport the debris to an EPA/State-approved landfill. This would create no adverse environmental impacts. The project has generated little public controversy and there are no unusual environmental concerns. These findings demonstrate that the proposed action is not a major Federal action significantly affecting the quality of the human environment within the meaning of the Nationai Environmental Policy Act (NEPA) of 1969. Therefore, the preparation of an Environmental Impact Statement (EIS) is not required and the Department is issuing this FONSI. FOR FURTHER PROJECT INFORMATION AND COPIES OF THE ENVIRONMENTAL ASSESSMENT CONTACT: John Taves, Environmental Coordinator for the Office of Engineering, Bonneville Power Administration, P.O. Box 3621-EFBG, Portland, Oregon 97208; telephone (503) 230-4995. FOR FURTHER INFORMATION REGARDING THE NATIONAL ENVIRONMENTAL POLICY ACT (NEPA) PROCESS CONTACT: Carol Borgstrom, Director, Office of NEPA Oversight, U.S. Department of Energy, 1000 Independence Avenue, S.W., Washington D.C. 20585; telephone (202) 586-4600 or (800) 472-2756. SUPPLEMENTARY INFORMATION: BPA Operations and Maintenance staff are currently based at a headquarters next to the Longview Substation. These headquarters buildings are undersized, outdated, and deteriorating. Surrounding development and the small size of the site 
prevents the construction of new buildings. BPA is concerned about the potential health risk from industrial fallout that appears to be damaging the headquarters equipment.

$\mathrm{BPA}$ proposes to close the existing maintenance headquarters and build a new one at the corner of Memorial Park Drive and 38th Avenue. The $\operatorname{Par} 3$ Golf alternative site has been identified at the intersection of 9 th Avenue and Wheeler Street. Due to potential wetland impacts, a third site was eliminated from consideration. BPA also evaluated and rejected the "No Action" alternative. Under this alternative, BPA staff would continue using undersized, outdated, and deteriorating headquarters buildings. The quality and efficiency of operations and maintenance activities would decline, and BPA would remain concerned about the potential health risk to the staff from industrial fallout. The new headquarters would consist of one to four buildings covering about 0.5 acres of a 5 -acre site. The buildings would contain offices, shops, storage areas, workshops, and garages, and would be surrounded by gravelled or paved parking and storage areas.

Both the proposed and alternative sites ace zoned as manufacturing districts and classified as light industrial in the City of Longview's Comprehensive Plan. Headquarters construction, therefore, is consistent with City land use plans. Once operating, vehicles accessing the headquarters would not noticeably affect existing traffic levels. The only listed or proposed threatened or endangered species in the area, the bald eagle and the peregrine falcon, would not be affected by the project. The labitats that would be modified by the project are not typically used by eagles or falcons. BPA would follow 
its noxious weed policy to assure that noxious weeds would not pose problems to surrounding lands. The history of the proposed site does not suggest the presence of hazardous materials. Furthermore, BPA sampled the site on April 2.3, 1991, and found only trace amounts of barium, chromium, and lead that were far below U.S. Environmental Protection Agency regulatory limits. The alternative site was not studied for the presence of such materials.

Section 404 of the Clean Water Act, passed in 1975, addresses the placement of fill material in wetlands. Because the proposed Solo Mountain site has been covered by fill since 1970, the Federal government does not have jurisdiction here and would not protect the site as a wetland. A visual inspection of the alternative site and soil samples taken next to the site did not indicate the presence of a wetland. The sites are not within floodplains, coastal zones, or shoreline management areas.

Drinking water sources would not be aifected by the maintenance headquarters. Surface and stormwater run-off would enter the City or County stormwater system and would meet all applicable Federal, State, and local standards. $0 i 1$ and water separators, detention basins, and other pollution control devices would be used where required. Polychlorinated Biphenyls (PCB's) would not be stored; however, trucks carrying $\mathrm{PCB}-\mathrm{containing}$ equipment may occasionally visit the headquarters. Small amounts of PCB's may also be present for a short time while equipment parts such as bushings are serviced. Other toxic and hazardous materials such as herbicides, engine oil, and solvents would be stored and disposed of in accordance with all applicable 
Federal, State, and local regulations including the Resource Conservation and Recovery Act, the Toxic Substances Control Act, the Comprehensive Environmental Response, Compensation, and Liability Act, and the Clean Water Act. Construction and operating the headquarters would not affect air quality.

Consultation with the Washington State Office of Archaeology and Historic Preservation found that no historic properties are known to exist at Elther the proposed or alternative sites. No archaeological materials were found at the sites during field surveys. Visual impacts of the headquarters building would be insignificant and recreation resources on public lands would not be affected. Energy conservation design features would be incorporated into the headquarters buildings.

PUBLIC AVAILABILITY: This FONSI will be distributed to all persons and agencies known to be interested in or affected by the proposed action or alternative.

DETERMINATION: Based on the information in the $\mathrm{EA}$, as summarized here, DOE determines that BPA's proposed action "is not a major federal action significantly affecting the quality of the human environment" within the meaning of NEPA, 42 U.S.C. 4321 et seq. Therefore, an EIS will not be prepared and DOE is issuing this FONSI.

Issued in Washington, D.C. on 1992

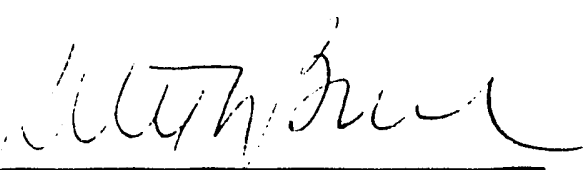

Paul L. Ziemer, Ph.D

Assistant Secretary

Environment, Safety and Health 

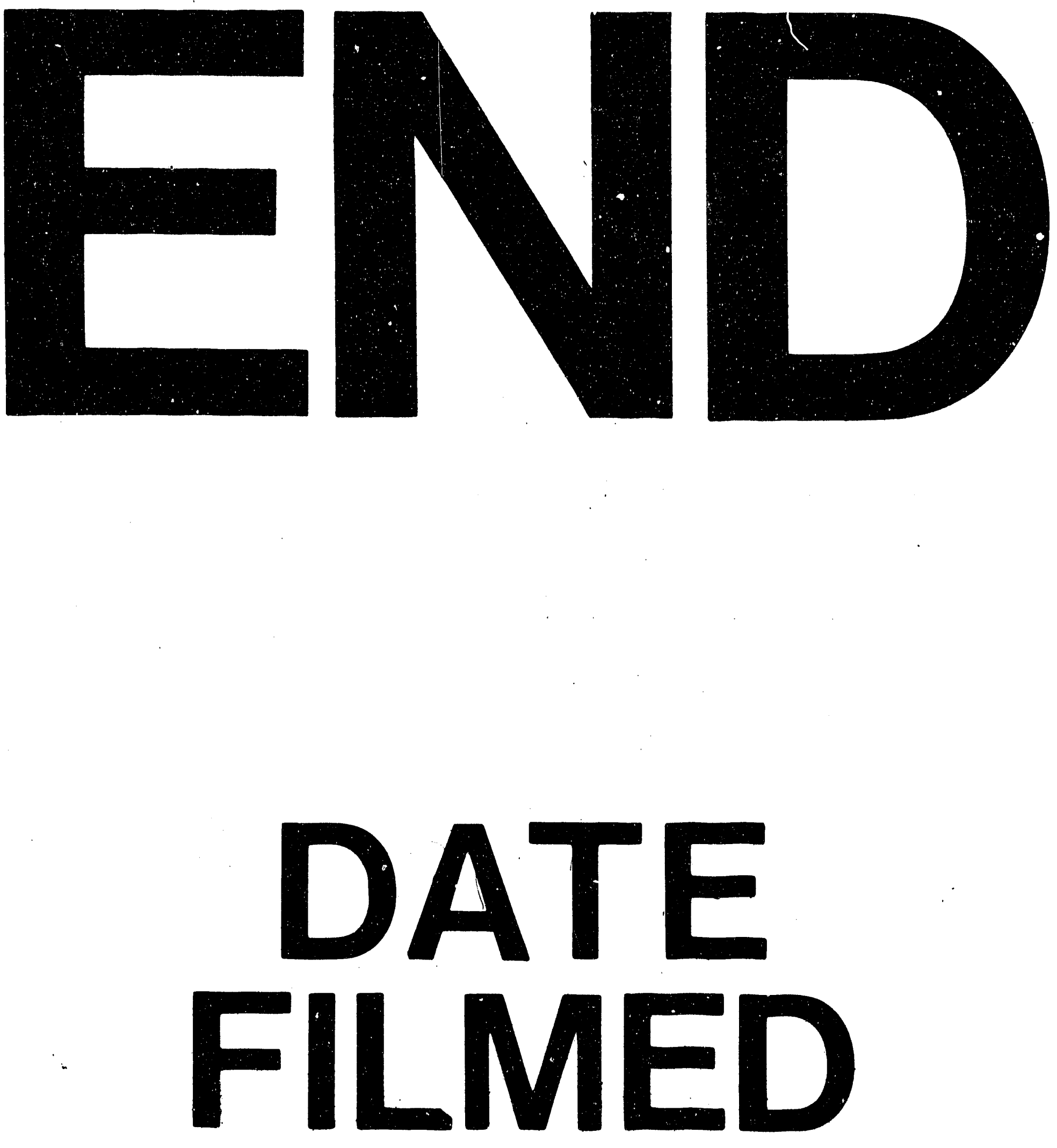

1

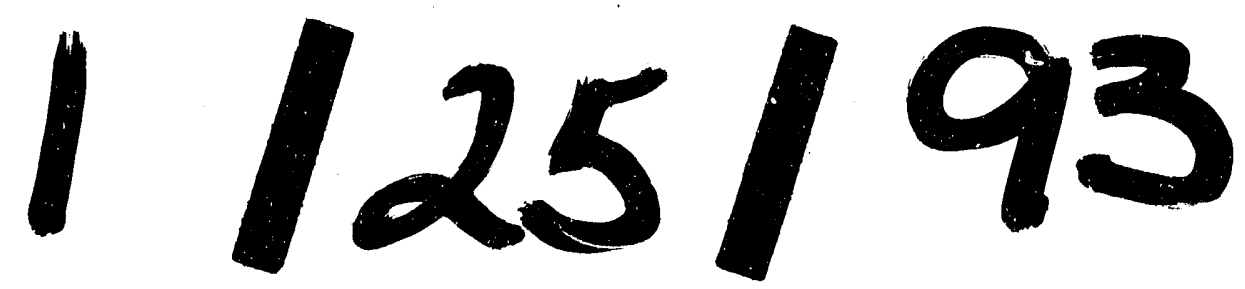

